6. Kushakova-Kostytska, N. V. (2013) "Methodological problems of modern legal research: objective necessity or subjective formality", Filosofski ta metodolohichni problemy prava, no. 1-2, pp. 23-31 [in Ukrainian].

7. Lukianova, H. Iu. (2011). "Methodological fundamentals of law research in modern legal science", Naukovyi visnyk Lvivskoho derzhavnoho universytetu vnutrishnikh sprav, no. 4, pp. 33-43.

8. Pashynskyi, V. I. (2017). „Methodological tools for studying problems of administrative and legal support for state defence", Visnyk Natsionalnoho tekhnichnoho universytetu Ukrainy «Kyivskyi politekhnichnyi instytut». Politolohiia. Sotsiolohiia. Pravo, no. 3-4, pp. 98-102. [in Ukrainian].

9. Rabinovych, P. M. (2001). Metodolohiia yurydychnoi nauky. Yurydychna entsyklopediia: $v$ 6 t. [Methodology of legal science. Legal Encyclopaedia: in 6 vols.]. Kyiv : Vyd-vo Ukrainska entsyklopediia imeni M.P. Bazhana. [in Ukrainian]

10. Holosnichenko, D. I. (2009). Teoriia Povnovazhen: vitchyznianyi ta zarubizhnyi dosvid yikh formuvannia: monohrafiia [Theory of credentials: the domestic and foreign experience of their formation: monograph]. Kyiv : H.A.M. [in Ukrainian]

11. (2006). "On Fulfilment of Decisions and Application of the European Court of Human Rights Practice": Law of Ukraine as of 23.02.2006 № 3477-IV, available at: https://zakon.rada.gov.ua/laws/show/3477-15 [in Ukrainian].

УДК $342.951: 351.82$

DOI https://doi.org/10.26661/2616-9444-2019-1-10

Значення основоположних принципів адміністративної процедури для забезпечення захисту прав громадян суб'сктами публічної адміністрації

Бєлінгіо В. О.

Київський національний університет імені Тараса Шевченка,

вул. Володимирська, 60, Київ, Україна

lera.belingio@gmail.com

Ключові слова:

принциии,

приничипи

адміністративної процедури,

види, ознаки та класифікація

принципів, захист прав

громадян суб'єктами публічної

адміністрації, загальні

принщиии, спещіальні принципи.

Надійшло до редколегії:

16.04.2019

Прийнято до друку: 23.05.2019
У статті досліджено доктринальні підходи до значення принципів адміністративної процедури у сфері забезпечення захисту прав громадян суб'єктами публічної адміністрації, розглянуто види й ознаки принципів адміністративної процедури. Запропоновано сучасний авторський підхід до поділу принципів адміністративної процедури на загальні та спеціальні. Розкрито правову природу загальних і спеціальних принципів адміністративної процедури, застосування яких суб'єктами публічної адміністрації є гарантією захисту прав громадян. 


\title{
Importance of the fundamental principles of the administrative procedure for ensuring protection of citizens' rights by public administration
}

\author{
Bielinhio V. O.
}

Taras Shevchenko National University of Kyiv, str. Volodymyrska, 60, Kyiv, Ukraine

lera.belingio@gmail.com

Key words:

principles, administrative procedure, types, features and classification of principles, protection of citizens' rights by public administration, general principles, special principles.
The article presents the doctrinal approaches to the importance of the principles of the administrative procedure in the field of ensuring protection of citizens' rights by public administration, the types and features of the principles of the administrative procedure are considered. A modern author's approach to classification of the principles of the administrative procedure into general and special is proposed. The general principles of the administrative procedure include: - the rule of law; - the principle of binding of public administration by legal law; - the principle of equality before the law, and the principle of non-discrimination; - the principle of the protection of legitimate expectations, or the duty of public administration to act fairly; - the principle of transparency and openness; - the principle of the protection of personal data; - the principle of legal certainty. By the special principles of the administrative procedure, the author enumerates: - the principle of the prohibition of abuse of formal requirements; - access to information; - assistance and representation; - indication of remedies; - the principle of efficiency; - the principle of presumption of lawful actions and requirements of a person; - the principle of proportionality; - the principle of the use of authority with proper intention; - silence procedure; - right to be heard; right to be informed; - duty of public administration to indicate the remedies; - the principle of co-requisitioning documents; - the principle of timeliness; - principle of appeal of administrative acts. The author reveals the legal nature of the general and special principles of the administrative procedure, the use of which by the public administration, is a guarantee of the protection of citizens' rights. The author draws attention to the fact that the special principles of the administrative procedure should include the principles enshrined in the Resolution (77) 31 on the Protection of the Individual in Relation to the Acts of Administrative Authorities. The author's position is justified by the fact that Ukraine has made the European integration choice, aimed at protecting of citizens' rights and interests.

\begin{abstract}
У вітчизняній науковій літературі значна увага вчених приділяється питанню принципів адміністративної процедури, зокрема ними запропоновано різноманітні підходи до їх класифікації. Науковий інтерес 3 боку дослідників до цього питання $\epsilon$ виправданим, адже адміністративна процедура - це врегульований адміністративнопроцесуальними нормами порядок учинення послідовних дій суб'єктами
\end{abstract}

публічної адміністрації шляхом розгляду й розв'язання індивідуальних справ фізичних i юридичних осіб 3 метою забезпечення та здійснення захисту їхніх прав i свобод. Порядок такого «співробітництва» між суб'єктами публічної адміністрації та фізичними/юридичними особами має регулюватися принципами, які $\epsilon$ керівними приписами для вчинення адміністративно-процедурної діяльності. 
До розгляду проблематики принципів адміністративної процедури та їх класифікації в працях зверталися такі науковці, як В.Б. Авер'янов, Ю.П. Битяк, Н.Л. Губерська, О.С. Лагода, Р.С. Мельник, С.П. Погребняк, А.А. Пухтецька, О.М. Соловйова, В.П. Тимощук, А.М. Школик та інші.

Однак актуальним залишається питання виокремлення принципів адміністративної процедури в діяльності суб'єктів публічної адміністрації щодо забезпечення захисту прав i законних інтересів громадян.

Метою статті $є$ дослідження принципів адміністративної процедури, які безпосередньо впливають на якість взаємодії громадян із суб'єктами публічної адміністрації та застосування яких забезпечує захист прав громадян суб'єктами публічної адміністрації.

На шляху становлення Української державності, що пройдено за роки іiї незалежності, вченимиадміністративістами напрацьовані певні підходи щодо видів та окремих класифікаційних ознак принципів адміністративної процедури.

I.В. Бойко, О.Т. Зима, О.М. Соловйова вважають, що для будьякого виду адміністративної процедури характерні такі принципи: верховенство права; законність; презумпція правомірності дій і вимог приватної особи; рівноправність; пропорційність; використання адміністративним органом своїх повноважень 3 метою, якою такі повноваження надані; безсторонність адміністративної процедури; добросовісність; розсудливість; своєчасність і розумний строк [1, с. 22-29].

В.П. Тимощук серед принципів адміністративної процедури виділяє законність, рівність, публічність, оперативність, ефективність, підконтрольність [2, с. 32-36].

Низка дослідників принципи адміністративної процедури поділяє на окремі групи.
О.С. Лагода,

О.М. Соловйова класифікують принципи адміністративної процедури на загальні (загальноправові) та галузеві $[3, \quad$ с. $17 ; 4$, с. 150$]$; Ю.О. Тихомиров, Е.В. Талапіна виділяють загальні принципи та принципи-норми [5, c. 4]; I.B. Криворучко визначає три групи принципів: конституційно-правові; організаційні; морально-етичні [6, с. 71]; В.Б. Авер'янов, Т.О. Коломоєць, С.Г. Стеценко пропонують поділяти принципи адміністративних процедур на загальні та спеціальні $[7$, с. 82 ; 8, с. 168 169; 9, c. 260].

Саме в цьому - сутність принципової відмінності, яка орієнтована на забезпечення прав та інтересів громадян.

Загальні принципи адміністративної процедури $\epsilon$ основою всієї процедурної діяльності суб'єктів публічної адміністрації, саме вони закладають базу для взаємодії між ними та приватними особами. Спеціальні уточнюють зміст загальних принципів i відображають сутність адміністративнопроцедурної діяльності суб'єктів публічної адміністрації. Очевидно, що для вирішення конкретних проблем правової теорії і практики розуміння прав людини загальні та спеціальні принципи адміністративної процедури потребують подальшого уточнення.

На нашу думку, загальні принципи адміністративної процедури варто доповнити принципом верховенства права; принципом зв'язаності публічної адміністрації правовим законом; принципом рівності перед законом, принципом недискримінації; принципом захисту законних очікувань, або обов'язком публічної адміністрації діяти справедливо; принципом гласності й відкритості; принципом захисту персональних даних; принципом правової визначеності.

Принщип верховенства права є керівним принципом, закріпленим у ст. 8 Основного Закону України [10]. Цей принцип означає забезпечення пріоритету 
прав людини перед будь-якими іншими цінностями соціальної, правової, демократичної держави та безумовне підпорядкування діяльності всіх державних інституцій і посадових осіб вимогам реалізації й захисту зазначених прав $[11$, с. 73$]$. Одним із проявів верховенства права $є$ те, що право не обмежується лише законодавством як однією 3 його форм, а містить у собі й інші регулятори, зокрема норми моралі, традиції, звичаї тощо, легітимовані суспільством і зумовлені історично досягнутим культурним рівнем суспільства. Окрім того, вирішення певної адміністративної справи має бути насамперед утіленням справедливості. Під час вирішення конкретної адміністративної справи публічна адміністрація повинна розглядати право не як закон чи систему нормативноправових актів, а як утілення справедливості [4, с. 150]. В.П. Тимощук, характеризуючи зміст принципу верховенства права в адміністративній процедурі, вказує на таке: 1) принцип верховенства права належить до конституційних та означає пріоритет прав i свобод людини, справедливість, гуманізм у діяльності публічної адміністрації; 2) для цього принципу «слід чітко розмежовувати такі дві категорії, як «закон» і «право», адже навіть закон може бути неправовим за процедурою його прийняття або за своїм змістом»; 3) «адміністративний орган в адміністративній процедурі повинен керуватися принципом верховенства права, який зобов'язує його не сліпо виконувати вимоги нормативного акта, а зважати на відповідність цього акта вищим за юридичною силою нормам права» [2, c. 32]. Тож одним із найважливіших принципів адміністративної процедури $\epsilon$ принцип верховенства права, який гарантує, що права i свободи людини $\epsilon$ найвищою цінністю в державі, саме цим цінностям підпорядкована діяльність суб'єктів публічної адміністрації під час вирішення індивідуальних справ громадян.

Принции зв'язаності публічної адміністрачії правовим законом. Суб'єкт публічної адміністрації в діяльності має керуватися не будь-яким законом, а лише тим, що $є$ правовим за своєю сутністю або, інакше кажучи, заснованим на принципі верховенства права [12, с. 53]. Цей принцип вимагає, щоб суб'єкти публічної адміністрації здійснювали свої повноваження виключно на підставі правового закону. Його метою $\epsilon$ обмеження повноважень суб'єктів публічної адміністрації правовим законом 3 ціллю захисту прав та свобод громадян. Крім того, на нашу думку, принцип зв'язаності публічної адміністрації правовим законом означає, що суб'єкти публічної адміністрації мають діяти виключно в рамках повноважень, визначених законодавством. Також розглядуваний нами принцип передбачає заборону суб'єктам публічної адміністрації зловживати наданою їм владою, адже їхня діяльність має відбуватися в рамках, дозволених i встановлених у чинному законодавстві.

Принщип рівності перед законом $i$ принщип недискримінації. У статті 24 Конституції України зафіксовано принцип рівності перед законом [10]. Метою закріплення принципу рівності учасників адміністративної процедури перед законом $є$ забезпечення збалансованості адміністративної процедури як змагальної між формально нерівними іiі учасниками, тобто вирівнювати відносини між публічною адміністрацією та приватною особою зважаючи на наділення суб'єкта адміністративного органу владними повноваженнями щодо особи $[13$, с. 36]. Науковець Р.С. Мельник наголошує, що продовженням конституційного принципу рівності громадян перед законом $\epsilon$ принциип недискримінації. Він має забезпечувати однакові «стартові» умови кожному громадянинові для самореалізації в суспільстві [12, с. 54-55]. Принцип недискримінації є ключовим у 
розумінні обгрунтованості дій і рішень публічної адміністрації, адже він заснований на функції вирівнювання, оскільки через певні життєві обставини або особливості особистого статусу $є$ різниця в правовому стані осіб. Як адміністративний орган, так і суд мають давати оцінку достатніх підстав для різного ставлення до осіб із неоднаковим статусом або однакового ставлення до осіб із подібним статусом. Мірилом правомірності різниці у ставленні $\epsilon$ трискладовий тест, згідно з яким різниця у ставленні має грунтуватися на законові, переслідувати легітимну мету під час застосування достатніх і доречних засобів [14, с. 158]. Отже, принцип рівності перед законом гарантує однакові можливості для всіх громадян, передбачає заборону суб'єктам публічної адміністрації приймати різні рішення у справах, які мають однакові фактичні обставини, а принцип недискримінації передбачає ідентичне ставлення до всіх учасників адміністративної процедури із забороню пригнічення чи виокремлення певних індивідів.

\begin{tabular}{llr}
\multicolumn{1}{c}{ Принциип } & захисту & законних \\
очікувань, або & обов'язок & публічної \\
адміністраиї & діяти & справедливо \\
передбачає, що діяльність & органів
\end{tabular} публічної адміністрації не повинна створювати перешкод у здійсненні громадянами їхніх безумовних прав, крім випадків, коли це $\epsilon$ необхідним в інтересах суспільства. Питання щодо законних очікувань, як правило, виникають тоді, коли рішення, прийняте суб'єктом публічної адміністрації, є таким, що може бути скасоване чи відкликане суб'єктом публічної адміністрації [15, с. 18]. Громадянин, керуючись цим принципом, покладається на дійсність рішення, прийнятого суб'єктом публічної адміністрації. Мова йде про те, що, якщо орган публічної адміністрації прийняв рішення на користь громадянина, але воно є незаконним, таке рішення не може бути скасовано чи відкликано суб'єктом публічної адміністрації, адже громадянин уже почав діяти на основі такого рішення, розраховуючи на його легітимність, наприклад, почав будувати будинок після отримання дозволу на будівництво [16, c. 203-204]. Цей принцип спрямований на унеможливлення зловживання владою органами публічної адміністрації, а отже, на захист прав громадян.

Принциии гласності й відкритості. Утілення цих принципів у життя зумовлюється необхідністю широкої поінформованості суспільства про діяльність державних органів, їх посадових i службових осіб щодо здійснення адміністративно-процедурних функцій [17, с. 210]. Принципи гласності й відкритості мають вагоме значення для захисту прав громадян. Усі учасники адміністративної процедури повинні мати однакове право доступу до інформації в межах адміністративної процедури, крім випадків, визначених законодавцем, коли вимагається обмеження в доступі до інформації.

Принции захисту персональних даних указує на те, що орган публічної адміністрації зобов'язується збирати, використовувати, поширювати та зберігати персональні дані громадян виключно в спосіб і 3 метою, регламентованою законодавством. Призначення цього принципу полягає в установленні обмеження процедури збирання, оброблення та зберігання персональних даних, включаючи часові обмеження для зберігання персональних даних та обмеження щодо якості й актуальності зібраної та збереженої інформації. Розглядуваний принцип $\epsilon$ індивідуальною гарантією приватної особи, необхідною в демократичному суспільстві, проти незаконного розкриття iii персональних даних суб'єктами публічної адміністрації [18, с. 275-276].

Принщип правової визначеності вимагає чіткого та зрозумілого формулювання правових норм. Дія цього принципу спрямована на те, щоб правові відносини, які регулюються 
законодавством,

залишалися

передбачуваними, тому що приватні особи повинні однозначно й чітко визначати свої права й обов'язки та бути в змозі вжити відповідних заходів [15, c. 17]. Крім того, вважаємо, що цей принцип передбачає, що громадянин повинен мати змогу легко визначити, коли й за яких умов набере чинності рішення, прийняте суб'єктом публічної адміністрації за результатом вирішення його індивідуальної адміністративної справи, i встановити конкретну дату початку дії правових наслідків від прийнятого щодо нього рішення.

До групи спеціальних принципів адміністративної процедури можна зарахувати такі: принцип заборони зловживання формальними вимогами; доступ до інформації; допомогу i представництво; зазначення засобів правового захисту; принцип ефективності; принцип презумпції правомірності дій i вимог особи; принцип пропорційності; принцип використання повноважень 3 належною метою; принцип «мовчазної згоди», право бути вислуханим; право бути проінформованим; обов'язок суб'єкта публічної адміністрації викласти підстави для прийняття рішення; принцип співмірно запитуваних документів; принцип своєчасності; принцип оскаржуваності адміністративних актів.

Принции заборони зловжсивання формальними вимогами полягає в забороні суб'єктам публічної адміністрації займатися бюрократією та відмовляти громадянам у вирішені їхніх індивідуальних справ тільки через формальні вимоги, які не сприяють ефективному та своєчасному вирішенню справи.

Достуn до інформаціiі. На запит особи, яка звертається до суб'єкта публічної адміністрації для отримання адміністративного акта, чи особи, на чиї права й інтереси може вплинути прийняття адміністративного акта, до прийняття адміністративного акта i належним чином повідомляють, про всі наявні факти, що мають стосунок щодо прийняття цього акта [19].

Допомога $i$ представництво.

Громадянам може надаватися допомога або може бути надано представника в адміністративній процедурі [19]. Наприклад, особі, яка звертається до Центру надання адміністративних послуг для реєстрації іiі місця проживання, може знадобитися фахова допомога щодо переліку документів, які необхідно подати для отримання такої послуги, строки надання послуги, порядок подання документів тощо. У зв'язку 3 цим доцільним було б надання безоплатної правової допомоги громадянам, які звертаються до суб'єктів публічної адміністрації.

Зазначення засобів правового захисту. Якщо адміністративний акт, який наданий у письмовій формі, несприятливо впливає на права, свободи чи інтереси громадянина, то в ньому вказуються звичайні засоби правового захисту від нього, а також строки їх використання [19].

Принцуип ефективності передбачає визначення мінімально обтяжливого для держави характеру ведення адміністративних справ [9, с. 263]. Тобто цей принцип в адміністративній процедурі забезпечує досягнення мети 3 якнайменшими затратами під час вирішення індивідуальної адміністративної справи громадянина.

Принциип презумпиії правомірності дій $i$ вимог особи. О.М. Соловйова наголошує, що рішення за зверненнями громадян не має грунтуватися на припущеннях, а всі сумніви стосовно правомірних вимог (дій) громадян, які звертаються до адміністративного органу, повинні тлумачитися на їхню користь [4, c. 154]. Поділяємо позицію вченої та зауважимо, що для суб'єкта публічної адміністрації дії й вимоги особи, яка до нього звернулася, апріорно мають бути правомірними, якщо інше не буде з'ясовано під час розгляду адміністративної справи. 
Принциип пропориійності. Як зазначає А.А. Пухтецька, цей принцип $\epsilon$ європейським адміністративного права, шо сформульовано ще наприкінці 80 -х років XX століття [20, c. 129-130]. Юридичними механізмами реалізації цього принципу є обов'язки адміністративного органу: використовувати повноваження лише 3 метою, для якої ці повноваження надано; зважати на негативні наслідки своїх рішень, дій і бездіяльності; співвідносити цілі прийняття рішення й умови їх досягнення [21, с. 203]. Тобто суб'єкт публічної адміністрації, приймаючи рішення щодо прав приватної особи, зобов'язаний забезпечити справедливу рівновагу між інтересами останньої та метою, на яку спрямована дія адміністративного акта.

\section{Приниип}

використання повноважень із належною метою. Н.Л. Губерська стверджує, що мета повноважень визначається в законі або випливає з його цілей і становить бажаний результат управління, окреслюючи, отже, основні напрями діяльності відповідного державного органу [22, с. 52].

Принции «мовчазної згоди» $\epsilon$ альтернативним способом отримання відповіді/рішення приватними особами. Так, рішення/відповідь уважається автоматично наданим (-ою) приватній особі, якщо орган публічної адміністрації протягом визначеного законом строку не надав таке рішення/відповідь заявнику. Після закінчення визначеного законом строку для надання відповіді/рішення та за відсутності такої (-го) відповіді/рішення вважається, що рішення щодо заявника прийнято на його користь. Метою цього принципу $\epsilon$ покращення діяльності суб'єктів публічної адміністрації шляхом спрощення адміністративних процедур i дисциплінування публічної адміністрації 3 метою дотримання нею строків, визначених законодавством.
Попередньо зазначено, що до групи спеціальних принципів адміністративної процедури належить право бути вислуханим, право бути проінформованим, обов'язок суб'єкта публічної адміністрації викласти підстави для прийняття рішення, принцип співмірно запитуваних документів, принцип своєчасності, принцип оскаржуваності адміністративних актів. Перераховані принципи є організаційними принципами діяльності належної публічної адміністрації, на думку автора, в повному складі охоплюються спеціальними принципами адміністративної процедури. Організаційні принципи діяльності належної публічної адміністрації $\epsilon$ керівними засадами, які слугують основою для забезпечення й захисту прав громадян публічною адміністрацією. А отже, під час адміністративнопроцедурної діяльності від суб'єктів публічної адміністрації вимагається підкорення згаданим принципам, а саме: право бути вислуханим [19] - право кожної людини бути почутою до того, як суб'єктом публічної адміністрації буде вжито будь-який індивідуальний захід, який може на неї вплинути, і право на повний доступ до інформації та документів, на підставі яких суб'єктом публічної адміністрації буде прийнято рішення; право бути проінформованим установлює обов'язок для суб'єкта публічної адміністрації повідомити громадянина про прийняте рішення, включаючи інформацію про право на оскарження такого рішення та можливу процедуру; обов'язок суб'єкта публічної адміністрачії викласти підстави для прийняття рішення [19], відповідно до якого суб'єкт публічної адміністрації повинен зазначити правові підстави для прийняття акта, описати фактичні обставини, що призвели до його прийняття, і загальні цілі, які він мав намір досягти; підстави мають бути сформульовані чітко й недвозначно, так, щоб дати можливість зацікавленим 
особам прийняти рішення, чи хочуть вони захищати свої права та інтереси шляхом подання заяви про перегляд прийнятого рішення в судовому порядку $[15$, с. $20 ; 16$, с. 27-28]; принции співмірно запитуваних документів указує на те, що органи публічної адміністрації повинні запитувати в приватних осіб необхідний мінімум інформації та документів, достатній для прийняття рішення; принщии своєчасності передбачає, що рішення мають прийматися суб'єктом публічної адміністрації протягом розумного строку, оскільки «повільна» публічна адміністрація $є$ неналежною адміністрацією; принции оскаржуваності адміністративних актів дає змогу приватним особам оскаржити адміністративний акт суб'єкта публічної адміністрації в позасудовому чи судовому порядку.

Проведення детального аналізу принципів адміністративної процедури дає змогу помітити, що до спеціальних принципів нами включено принципи, закріплені в Резолюції Комітету Міністрів Ради Європи (77) 31 про захист особи щодо актів адміністративних органів, а саме: право бути вислуханим; право на доступ до інформації; право на допомогу і представництво; виклад мотивів; зазначення засобів правового захисту.
Інтегрування цих принципів у національну правову систему відповідає сучасним тенденціям розвитку України, 3 огляду на обраний державою європейський напрям розвитку. Підкорення суб'єктів публічної адміністрації європейським принципам стане гарантією захисту прав приватних осіб під час розгляду та розв'язання їхніх індивідуальних справ. Дуже важливо реально закріпити вказані європейські принципи в українському законодавстві в кодифікованому акті, присвяченому систематизації адміністративнопроцедурної діяльності суб'єктів публічної адміністрації, або в окремому законі про адміністративну процедуру.

Проведене дослідження дає змогу дійти висновку, що сучасний підхід до застосування принципів адміністративної процедури суб'єктами публічної адміністрації у сфері захисту прав громадян - це не просто далекосяжний намір чи бажання, а нагальна життєва необхідність, котра органічно пов'язана 3 євроінтеграційним вибором України, адже вітчизняне адміністративне право за своїм «духом», за своєю суспільною спрямованістю, як й адміністративне право країн Європи, має бути орієнтовано на забезпечення прав та інтересів людей, їх ефективний захист.

\section{Література}

1. Бойко I. В., Зима О. Т., Соловйова О. М. Адміністративна процедура : конспект лекцій / за заг. ред. І. В. Бойко. Харків : Право, 2017. 132 с.

2. Адміністративна процедура та адміністративні послуги. Зарубіжний досвід i пропозиції для України / авт.-упоряд. В. П. Тимощук. Київ : Факт, 2003. 496 с.

3. Лагода О. С. Адміністративна процедура : теорія і практика застосування : автореф. дис. ... канд. юрид. наук : спец. 12.00.07. Ірпінь, 2007. 28 с.

4. Соловйова О. М. Принципи адміністративної процедури. Вісник Харківського нащіонального університету ім. В. Н. Каразіна. Серія «Право». 2011. № 988. Вип. 10. C. $149-155$.

5. Тихомиров Ю. А., Талапина Э. В. Административные процедуры и право. Журнал российского права. 2002. № 4. С. 3-13.

6. Криворучко I. В. Класифікація принципів адміністративної процедури та іiі застосування наукою державного управління. Науковий вісник Академії 
муніципального управління. Серія «Управління» / за заг. ред. О. І. Дація. Київ : АМУ, 2016. Вип. 1. С. 64-74.

7. Адміністративне право України: Академічний курс: підручник: у 2 т. / ред. колегія : В. Б. Авер'янов (голова). Київ : Юрид. думка, 2004. Т. 1 : Загальна частина. $584 \mathrm{c}$.

8. Коломоєць Т. О. Адміністративне право України. Академічний курс : підручник. Київ : Юрінком Інтер, 2011. 576 с.

9. Стеценко С. Г. Адміністративне право України : навч. посіб. Київ : Атіка, 2008. 624 с.

10. Конституція України : Закон України від 28 червня 1996 р. (зі змінами) / Верховна Рада України. URL : https ://zakon.rada.gov.ua/laws/show/254\%D0\%BA/96$\% \mathrm{D} 0 \% \mathrm{~B} 2 \% \mathrm{D} 1 \% 80$.

11. Авер'янов В. Б. Принцип верховенства права у сфері виконавчої влади : питання теорії та практики реалізації. Право Украӥни. 2010. № 2. С. 72-79.

12. Мельник Р. Інститут принципів адміністративного права у системі Загального адміністративного права України. Публічне право. 2012. № 3 (7). C. 51-60. URL: http ://www.yourfuture.org.ua/ua/pb/2012/7/Melnyk.pdf.

13. Криворучко I. Конституційно-правові принципи адміністративної процедури в Україні. Державне управління та місиеве самоврядування. 2016. Вип. 2 (29). С. $33-$ 39. URL : http ://nbuv.gov.ua/UJRN/dums_2016_2_6.

14. Публічне урядування, права людини і демократія : регіональний зріз євроінтеграції : монографія / за заг. ред. М. В. Савчина. Ужгород : Говерла, 2015. 320 с. URL : https ://dspace.uzhnu.edu.ua/jspui/bitstream/lib/9750/1/\%D0\%9C\%D0\%BE\%D0\%BD\%D 0\%BE\%D0\%B3\%D1\%80\%D0\%B0\%D1\%84\%D1\%96\%D1\%8F\%202015-1.pdf.

15. Diana-Urania Galetta, Herwig C. H. Hofmann, Oriol Mir Puigpelat, Jacques Ziller. The General Principles of EU Administrative Procedural Law - In-depth analysis for the JURI Committee. European Parliament. Brussels. 2015. 26 p. URL: http ://www.europarl.europa.eu/RegData/etudes/IDAN/2015/519224/IPOL_IDA\%282015 \%29519224_EN.pdf.

16. Nolte G. General Principles of German and European Administrative Law - A Comparison in Historical Perspective. The Modern Law Review. 1994. Vol. 57. № 2. P. 191-212. URL : https ://onlinelibrary.wiley.com/doi/pdf/10.1111/j.1468-2230.1994.tb01932.x.

17. Административное право Украины : учебник для студ. высш. учеб. заведений юрид. спец. / под ред. проф. Ю. П. Битяка. 2-е изд., перераб. и доп. Харьков : Право, 2003. $576 \mathrm{c}$.

18. Brouwer E. Legality and Data Protection Law: The Forgotten Purpose of Purpose Limitation. The Eclipse of the Legality Principle in the European Union / By Leonard F. M. Besselink, Frans Pennings, Sacha Prechal. The Netherlands: Kluwer Law International BV. 2011. pp. 273-294. URL: https ://dspace.library.uu.nl/bitstream/handle/1874/240364/brouwererch14legalityanddateprotection.pdf? sequence $=1$.

19. Resolution (77) 31 on the Protection of the Individual in Relation to the Acts of Administrative Authorities. Council of Europe: Committee of Ministers. 28.09.1977. URL : http ://www.refworld.org/docid/5a4caf0a4.html. 
20. Пухтецька А. А. Свропейські принципи адміністративного права та їх джерела. Актуальні проблеми держави $i$ права. 2007. С. 128-132. URL: http ://www.apdp.in.ua/v35/29.pdf.

21. Державне управління : проблеми адміністративно-правової теорії та практики / за заг. ред. В. Б. Авер'янова. Київ : Факт, 2003. 384 с. URL : https ://lawbook.online/ukrainyi-pravo-administrativnoe/derjavne-upravlinnya-problemiadministrativno.html.

22. Губерська Н. Л. Основні принципи організації та реалізації адміністративних процедур. Публічне право. 2015. № 1 (17). С. 48-56. URL : http ://nbuv.gov.ua/UJRN/pp_2015_1_8.

\section{References}

1. Boiko, I. V., Zyma, O. T. and Soloviova, O. M. (2017), Administratyvna protsedura: konspekt lektsii [Administrative procedure : a compendium of lectures], Pravo, Kharkiv, Ukraine.

2. Tymoshchuk, V. P. (2003), Administratyvna protsedura ta administratyvni posluhy. Zarubizhnyi dosvid i propozytsii dlia Ukrainy [administrative procedure and administrative services. Foreign experience and proposals for Ukraine], Fakt, Kyiv, Ukraine.

3. Lahoda O.S. (2007), Administrative procedure : theory and practice of application, Thesis abstract for Cand. Sc. (Jurisprudence), 12.00.07, Irpin, Ukraine.

4. Soloviova, O. M. (2011), Principles of administrative procedure, Visnyk Kharkivskoho natsionalnoho universytetu im. V.N. Karazina. Seriia : Pravo, no. 988, Iss. 10, pp. 149155.

5. Tihomirov, Yu. A., Talapina, E. V. (2002), Administrative procedures and law, Zhurnal rossiiskoho prava, no. 4, pp. 3-13.

6. Kryvoruchko, I. V. (2016), Classification of the principles of administrative procedure and its application by public administration science, Naukovyi visnyk Akademii munitsypalnoho upravlinnia. Seriia : Upravlinnia, Iss. 1, pp. 64-74.

7. Averianov, V. B. (2004), Administratyvne pravo Ukrainy: Akademichnyi kurs: pidruchnyk: $u 2 t$. [Administrative law of Ukraine : academic course : a textbook : in 2 vols.], Vol. 1 : Zahalna chastyna [General part], Yurydychna dumka, Kyiv, Ukraine.

8. Kolomoiets, T. O. (2011), Administratyvne pravo Ukrainy. Akademichnyi kurs: pidruchnyk [Administrative law of Ukraine. Academic course : a textbook], Yurinkom Inter, Kyiv, Ukraine.

9. Stetsenko, S. H. (2008), Administratyvne pravo Ukrainy : navch. posib. [Administrative law of Ukraine : a study guide], Atika, Kyiv, Ukraine.

10. The Constitution of Ukraine : the Law of Ukraine dated June 28, 1996 (as amended), available at : https ://zakon.rada.gov.ua/laws/show/254\%D0\%BA/96-\%D0\%B2\%D1\%80.

11. Averianov, V. B. (2010), The principle of rule of law in executive authority : issues of theory and practical implementation, Pravo Ukrainy, no. 2, pp. 72-79.

12. Melnyk, R. (2012), The institute of principles of administrative law in the system of General administrative law of Ukraine, Публічне право, nо. 3 (7), pp. 51-60, available at : http ://www.yourfuture.org.ua/ua/pb/2012/7/Melnyk.pdf. 
13. Kryvoruchko, I. (2016), Constitutional-legal principles of administrative procedure in Ukraine, Derzhavne upravlinnia ta mistseve samovriaduvannia, Iss. 2 (29), pp. 33-39, available at : http ://nbuv.gov.ua/UJRN/dums_2016_2_6.

14. Savchyn, M. V. (2015), Publichne uriaduvannia, prava liudyny i demokratiia : rehionalnyi zriz yevrointehratsii : monohrafiia [Public administration, human rights and democracy : regional statistics of European integration : a monograph], Hoverla, Uzhhorod, Ukraine, available

at : https ://dspace.uzhnu.edu.ua/jspui/bitstream/lib/9750/1/\%D0\%9C\%D0\%BE\%D0\%BD\%D 0\%BE\%D0\%B3\%D1\%80\%D0\%B0\%D1\%84\%D1\%96\%D1\%8F\%202015-1.pdf.

15. Diana-Urania Galetta, Herwig, C. H. Hofmann, Oriol Mir Puigpelat and Jacques Ziller (2015), The General Principles of EU Administrative Procedural Law - In-depth analysis for the JURI Committee. European Parliament. Brussels, 26 p., available at: http ://www.europarl.europa.eu/RegData/etudes/IDAN/2015/519224/IPOL_IDA\%282015 \%29519224_EN.pdf.

16. Nolte, G. (1994), General Principles of German and European Administrative Law - A Comparison in Historical Perspective, The Modern Law Review, Vol. 57, № 2, pp. 191212. available at : https ://onlinelibrary.wiley.com/doi/pdf/10.1111/j.14682230.1994.tb01932.x.

17. Bytiak, Yu. P. (2003), Admynystratyvnoe pravo Ukraynbl : uchebnyk dlia stud. vblssh. ucheb. zavedenyi yuryd. spets. [Administrative law of Ukraine : a textbook for students of higher ed. inst. of law sp.], Pravo, Kharkiv, Ukraine.

18. Brouwer, E., Leonard, F. M. Besselink, Frans Pennings and Sacha Prechal (2011), Legality and Data Protection Law: The Forgotten Purpose of Purpose Limitation. The Eclipse of the Legality Principle in the European Union, Kluwer Law International BV, The Netherlands, pp. 273-294. available at : https ://dspace.library.uu.nl/bitstream/handle/1874/240364/brouwererch14legalityanddateprotection.pdf? sequence $=1$.

19. Resolution (77) 31 on the Protection of the Individual in Relation to the Acts of Administrative Authorities. Council of Europe: Committee of Ministers. 28.09.1977, available at : http ://www.refworld.org/docid/5a4caf0a4.html.

20. Pukhtetska, A. A. (2007), European principles of administrative elaw and their sources, Aktualni problemy derzhavy $i$ prava, pp. 128-132, available at: http ://www.apdp.in.ua/v35/29.pdf.

21. Averianov, V. B. (2003), Derzhavne upravlinnia: problemy administratyvno-pravovoi teorii ta praktyky [Public administration : problems of administrative theory and practice], Fakt, Kyiv, Ukraine, available at: https ://lawbook.online/ukrainyi-pravoadministrativnoe/derjavne-upravlinnya-problemi-administrativno.html.

22. Huberska, N. L. (2015), Basic principles of the organisation and implementation of administrative procedures, Publichne pravo, no. 1 (17), pp. 48-56, available at: http ://nbuv.gov.ua/UJRN/pp_2015_1_8. 